\title{
MASSIVE GOITRE (STRUMA PARENCHYMATOSA) IN GEESE
}

\author{
Éva IVANICS ${ }^{1}$, P. RUdAS ${ }^{2}$, G. SÁlYI ${ }^{1}$ and R. GLÁVITS ${ }^{1}$ \\ ${ }^{1}$ Central Veterinary Institute, H-1 149 Budapest, Tábornok u. 2, Hungary; \\ ${ }^{2}$ Department of Physiology and Biochemistry, University of Veterinary Science, \\ Budapest, Hungary
}

(Received November 18, 1998; accepted January 12, 1999)

In a goose flock consisting of 2300 birds of 6 months of age severe goitre was diagnosed. To the best of our knowledge this is the first report of naturally occurring goitre in geese, which is not related to the feeding of rapeseed meal. The major pathological findings included retarded growth and plumage development, significantly $(300 \%)$ increased relative thyroid weight, fat accumulation in the mesenteric and abdominal region, and lipid infiltration of liver and kidney cells. Subsequent hormone analysis showed undetectable thyroxine $\left(T_{4}\right)$ levels and a dramatic drop in triiodothyronine $\left(\mathrm{T}_{3}\right)$ plasma levels of the diseased geese. Thyroidal histology displayed the typical signs of struma parenchymatosa. In order to get more information about the possible causes of the goitre, 10 geese from the affected farm were transferred into the laboratories of the Central Veterinary Institute. The geese were allotted into two groups. Group I received iodine supplementation for 55 days, while the other group served as sick control (Group S). Iodine treatment caused a dramatic improvement in the birds' clinical condition except in plumage growth in Group I, while the clinical and main pathological signs of goitre remained unchanged or worsened in the untreated Group S. Contrary to this, the serum levels of thyroid hormones and responsiveness to thyrotropin releasing hormone (TRH) improved not only in Group I but also in Group S. Almost euthyroid biochemical parameters were found after 55 days of iodine treatment in Group I and, surprisingly, a considerable improvement (especially in serum $\mathrm{T}_{3}$ levels) occurred also in Group S. These findings confirm the diagnosis of goitre but also call attention to the fact that iodine deficiency was not the only factor eliciting the disorder. The underlying possible goitrogenic substance could not be traced down.

Key words: Goitre, goose, pathological findings, hormone analysis

Goitre is a non-inflammatory, non-neoplastic enlargement of the thyroid gland that occurs in both humans and animals, in mammals and birds alike (Kapp, 1952; Bokori, 1956; Baker and Lindsey, 1968; Rac et al., 1968; Antal, 1972; Lissitzky et al., 1973; Kardeván, 1976; de Vijlder et al., 1978; Nesbitt et

"E-mail: eva_ivanics@ccmail.oai.hu; Fax: (36 1)252 5177 
al., 1980; Gosselin et al., 1980, 1981; Milne and Hayes, 1981; Robinson et al., 1988; Capen, 1993). Goitre may develop most often as a result of insufficient amounts of iodine in the diet or drinking water (Bokori, 1956; Kardeván, 1976; Antal, 1972; Capen, 1993). Other causative factors are the presence of goitrogenic substances in the feed (Kardeván, 1976; Capen, 1993), less frequently excess iodine in the feed (Baker and Lindsey, 1968) or rarely the genetically determined lack of thyroid hormone production (Rac et al., 1968; Lissitzky, 1973; Kardeván, 1976; de Vijlder et al., 1978; Pammenter et al., 1978; Capen, 1993).

In all the above cases a major physiological factor leads to the enlargement of the thyroid gland. The thyroid is unable to produce enough hormones and thus the level of circulating thyroxine $\left(\mathrm{T}_{4}\right)$ and triiodothyronine $\left(\mathrm{T}_{3}\right)$ drops in the plasma (Belshaw and Rijnberk, 1979; Capen, 1993). This in turn elicits an excess production of the thyroid stimulating hormone (thyrotropin, TSH) from the pituitary. TSH then causes all thyroidal functions to increase: hypertrophy and hyperplasia of the follicular epithelial cells occurs but due to the underlying factors hormone production is not possible. This leads to a vicious circle where TSH effects on the thyroid may lead to the total disappearance of follicular colloid, leaving behind hyperplastic follicles: struma parenchymatosa develops (Kardeván, 1976; Gosselin et al., 1980; Capen, 1993).

The major factor which causes the clinical symptoms in goitre to appear is the lack of thyroid hormones in the blood (hypothyroidism). In birds one of the major effects of hypothyroidism is retarded growth, feathering disorders and accumulation of adipose tissue in the abdomen (for a summary see Janan and Rudas, 1998). There are, however, several complications which may arise from the enlargement of the thyroid tissue itself: the enlarged mass compresses the surrounding tissues (trachea, oesophagus, vessels and nerves) in the cervical area (Kardeván, 1976; Capen, 1993).

Reports on endemic animal goitre are available from the most diverse geographical territories such as North America, Europe and Australia, mostly pinpointing well-defined districts of certain countries, e.g. Germany, the Netherlands, Norway, Russia (the Ural Mountains), Serbia and Switzerland (Kardeván, 1976; Capen, 1993). In Hungary three mountainous areas (Bükk, Mátra, Mecsek) display regions where goitre occurs quite frequently (Kardeván, 1976).

Sporadic goitre was reported in many bird species including parrots and doves (Kardeván, 1976), as well as in birds kept in zoos (32 such species were described by Wisser and Ippen, 1991). To our knowledge, naturally occurring goitre has not yet been reported in geese.

The present paper describes one of the rare natural occurrences of goitre in geese kept on a large-scale farm. The nature of this goitre was further investigated in our laboratory under experimental conditions, which is also reported here. 


\section{Materials and methods}

\section{Clinical signs and observation of the goose flock}

The goitre occurred on a large-scale goose farm in Kecskemét, where 2600 geese aged 6.5 months were kept in an adobe roost. The birds were allowed to pasture regularly. As a supplement, the geese were regularly turned out to pasture on the local rye field. They were kept on a starter and grower feed until 9 weeks of age and then on grain until 5 months of age. Subsequently fresh maize was offered. Water from a bored-type well served as drinking water throughout the raising period.

The birds were treated with Clamoxil at the age of 13 days. Within the plucking periods SCP 625 (containing sulfachlorpyridazine and trimethoprim) was applied for 3 days. After the third plucking the former treatment was supplemented by adding Trierra (containing furazolidone, zinc-bacitracin and oxytetracycline) for a 7-day period.

The geese were plucked first at 2 months of age and every 45 days thereafter, altogether four times.

Clinical signs of the illness were investigated at the site of raising and, in the case of 10 geese, at the Central Veterinary Institute (CVI) where these animals were transferred to for experimental purposes.

\section{Pathological, histological and bacteriological findings}

The eight 8 geese that died on the farm and the birds transferred to the CVI were subjected to postmortem examination. The thyroid gland, parathyroid gland, liver, kidney, testis, ovary and, in some instances, the ultimobranchial organ and adrenals of the birds were examined histologically. Tissue samples were fixed in $10 \%$ neutral ( $\mathrm{pH} \mathrm{7.2)} \mathrm{formaldehyde} \mathrm{and} \mathrm{processed} \mathrm{by} \mathrm{freezing} \mathrm{and} \mathrm{em-}$ bedding in paraffin. For general investigations the samples were stained with haematoxylin and eosin. Special staining involved the fat-red method to indicate the presence of lipids in the liver and kidney samples.

Bacteriology was done according to the standard protocols of the CVI from the heart blood and liver of the geese.

\section{Animal experiments}

Six geese (Group A) out of the 10 birds showing clinical signs of plumage problems and transported from the farm to the Institute were blood sampled on Day 1. On Day 2 the birds were randomly allotted into two groups of 5 individuals each. The geese in Group I (iodine-treated group) were treated for 4 weeks with Lugol's solution via an oesophageal tube in a dose equivalent to $2 \mu \mathrm{g}$ iodine $/ \mathrm{kg}$ body weight/day. The daily iodine dose was increased to $50 \mu \mathrm{g}$ between week 5 and week 8 of the experiment. The geese of Group S (sick control birds) were left 
untreated throughout the period of experiment. In the first 6 weeks of the experiment these 10 geese were fed ad libitum with the original maize obtained from the farm. Later on maize was obtained from other sources. In the assessment of the biochemical parameters of thyroid activity five additional geese of the same age from an unaffected farm were used as normal controls (Group N).

\section{Biochemical parameters of thyroid status}

Plasma thyroxine $\left(T_{4}\right)$ and triiodothyronine $\left(T_{3}\right)$ concentrations were first measured in 6 geese (Group A) randomly selected from the 10 animals one day after arrival at the Institute, before allotting them into Group I and Group S. Further hormone measurements were carried out on Day 25 and Day 55 from Group I and Group S. The measurements of hormone concentrations were carried out by radioimmunoassay (Pethes et al., 1978a, 1978b). In the animals transferred to the laboratory TRH (thyrotropin releasing hormone) provocation test was performed (in the case of Groups A and N on Day 0 and in the case of Groups I and S on Day 25) to check the responsiveness of the pituitary-thyroid axis and the possible effectiveness of iodine supplementation. This entailed the following. After drawing " 0 " time blood sample, geese were given $10 \mu \mathrm{g}$ TRH/ $\mathrm{kg}$ body weight (Sigma Chemical Co., St. Louis, MO, USA) intravenously. Forty minutes thereafter a blood sample was taken again. The changes in the concentration of $T_{4}$ and $T_{3}$ in the blood sample taken before and after TRH injection were expressed in percentage of the original hormone concentrations.

\section{Results}

\section{Clinical symptoms and the course of the disease}

Signs of a disease were first discovered in the stock at 6 months of age after the fourth plucking in mid-October. At that time the body weight dropped to an average of $4.7 \mathrm{~kg}$ as compared to the $5.0 \mathrm{~kg}$ measured at the previous plucking. The overall amount of down gained (130-140 g per animal) was also way below the $170 \mathrm{~g}$ average obtained at the previous time. All birds displayed lack of appetite and retarded plumage growth even after 5 weeks in the postplucking period. Deaths began to occur and at that time 6-8 animals died per day. Contrary to our advice, iodine supplementation was not given to the flock and the situation worsened day by day. Finally the whole flock had to be slaughtered and sold as table goose in December, since no hope for recovery from the plumage problems and weight loss could be foreseen. 


\section{Pathological, histological and bacteriological findings}

One of the main pathological findings was the uneven growth and development of geese of the same age. Body weight ranged between 3550-5800 g and considerable underdevelopment or lack of plumage was seen on the breast, abdomen and back of the birds (Fig. 1). The integument remained normal. Within the subcutaneous connective tissue and also in the intraabdominal and mesenteric region a large amount of fat had accumulated. Livers and kidneys had a yellowish colour and the surface of the sectioned organs displayed fatty shine. The texture of the tissues was easy to tear apart.

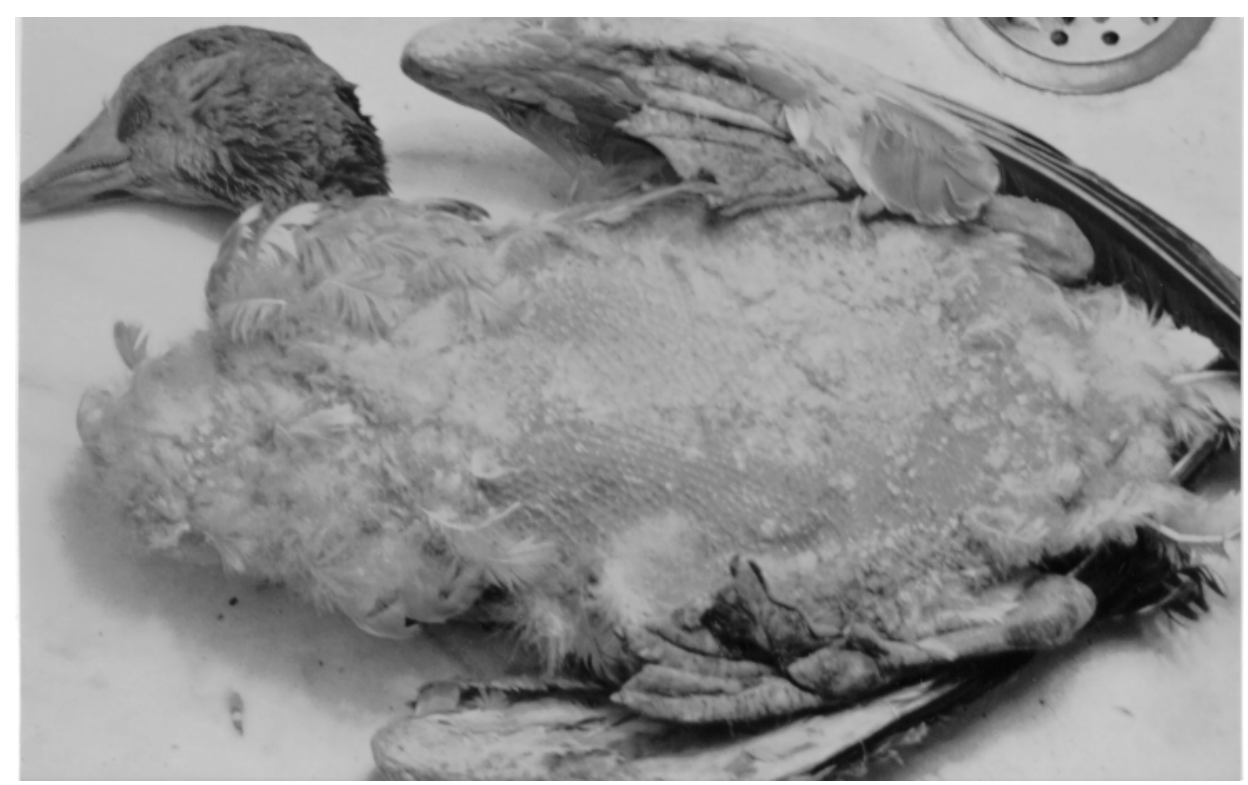

Fig. 1. Retarded plumage development was seen even 5 weeks after plucking

On the two sides of the trachea a proportional and symmetrical enlargement of the thyroid glands was found. The brownish-red enlarged mass of the glands was dense to the touch (Figs 2 and 3). The total mass of the thyroids in these birds was twice larger than that measured in normal flocks of geese of the same age from other farms. When the weight of the thyroids was expressed in percentage of body weight, it was found to be three times higher than in normal geese (Table 1). No pathological signs were found in any other tissue. 


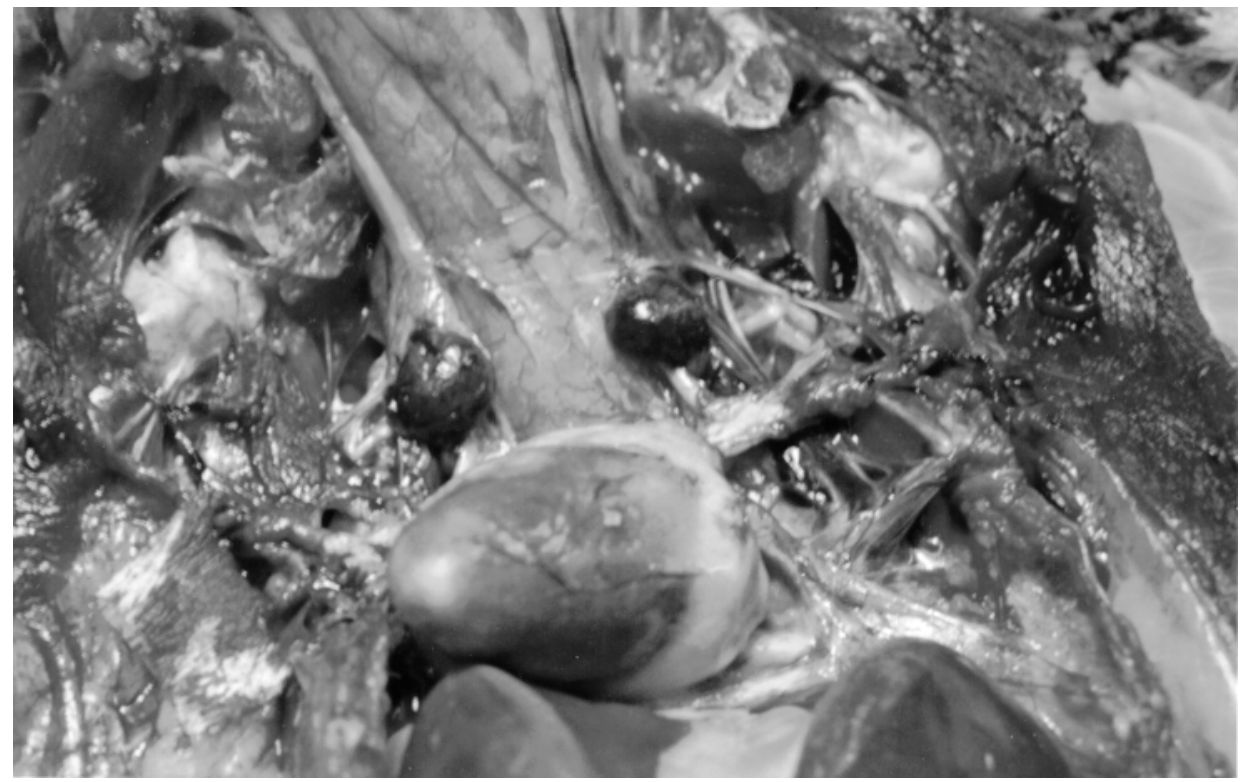

Fig. 2. The thyroid glands of diseased geese are swollen, brownish-red in colour and protruding from their surrounding around the trachea

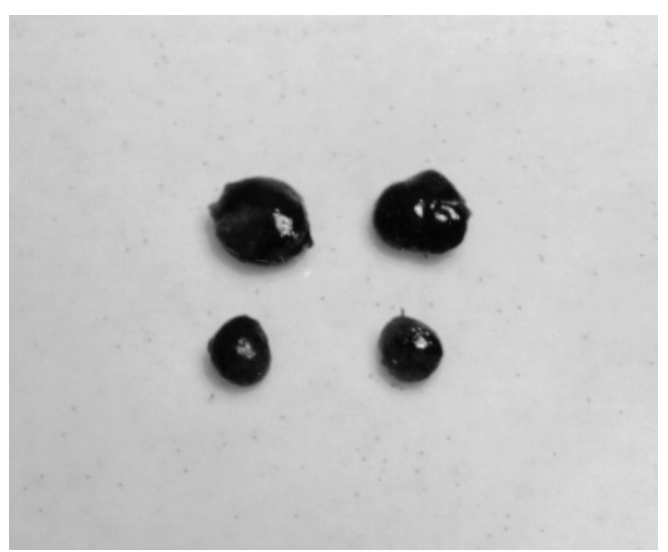

Fig. 3. Dramatically enlarged thyroid glands in sick birds as compared to thyroids of healthy geese of the same age (lower row) 


\section{Table 1}

Panel A: The absolute and relative mass of the thyroid glands in 5 healthy geese from an unaffected farm and in geese displaying goitre at the time of discovering the abnormality in the affected farm. Panel B: The same parameters of iodine-treated (Group I) and untreated sick (Group S) geese at the end of the laboratory experiment. Absolute mass in gram, relative mass in \% of body weight,

average \pm SEM $(\mathrm{N})$. Groups with same superscripts $\left({ }^{\mathrm{a}}\right.$ through ${ }^{\mathrm{d}}$ ) differ significantly, $\mathrm{P}<0.05$

\begin{tabular}{ccc}
\hline \multicolumn{1}{c}{ Panel A } & Healthy geese & Geese displaying goitre \\
\hline $\begin{array}{l}\text { Thyroid mass (g) } \\
\text { Thyroid mass/body weight \% }\end{array}$ & $\begin{array}{l}0.644 \pm 0.061(5)^{\mathrm{a}} \\
0.0099 \pm 0.0007(5)^{\mathrm{b}}\end{array}$ & $\begin{array}{l}1.304 \pm 0.103(5)^{\mathrm{a}} \\
0.0290 \pm 0.0016(5)^{\mathrm{b}}\end{array}$ \\
\hline \multicolumn{1}{c}{ Panel B } & Group I & Group S \\
\hline Thyroid mass (g) & $0.323 \pm 0.054(5)^{\mathrm{c}}$ & $0.830 \pm 0.162(5)^{\mathrm{c}}$ \\
Thyroid mass/body weight \% & $0.0076 \pm 0.0006(5)^{\mathrm{d}}$ & $0.0213 \pm 0.0039(5)^{\mathrm{d}}$ \\
\hline
\end{tabular}

In the affected geese the histology of the thyroid gland - as compared to the control (Figs 4 and 5) - showed a considerably decreased follicular colloid content or sometimes a total lack of colloid in the follicles. The epithelial layer of the follicles grew to cubic or cylindrical in appearance and in many cases the cells occupied the follicular lumen in several layers (Figs 6 and 7). In some instances one could detect vacuoles in the cytoplasm of the follicular epithelial cells. In the connective tissue of the thyroid gland, among the follicles the number and diameter of blood vessels were increased.

Vacuoles in the cytoplasm of liver cells occupied the whole intracytoplasmic space, pushing the nucleus of cells towards the plasma membrane (Fig. 8). Within the vacuoles lipid droplets appeared as demonstrated by specific staining. Fat appeared either in stripes or in a diffuse manner within the liver tissue, exhibiting great individual variance. Lipid-containing vacuoles could also be detected in the tubular system of some of the kidneys examined.

The extent of liver and kidney damage was proportional to the severity of thyroidal findings.

By systematic investigations from heart blood and liver the presence of no pathogenic bacterium could be substantiated.

Mycological investigation of the maize originating from the farm showed an elevated mould concentration $(16,000 \mathrm{CFU} / \mathrm{g})$. All moulds belonged to the Acremonium species. 


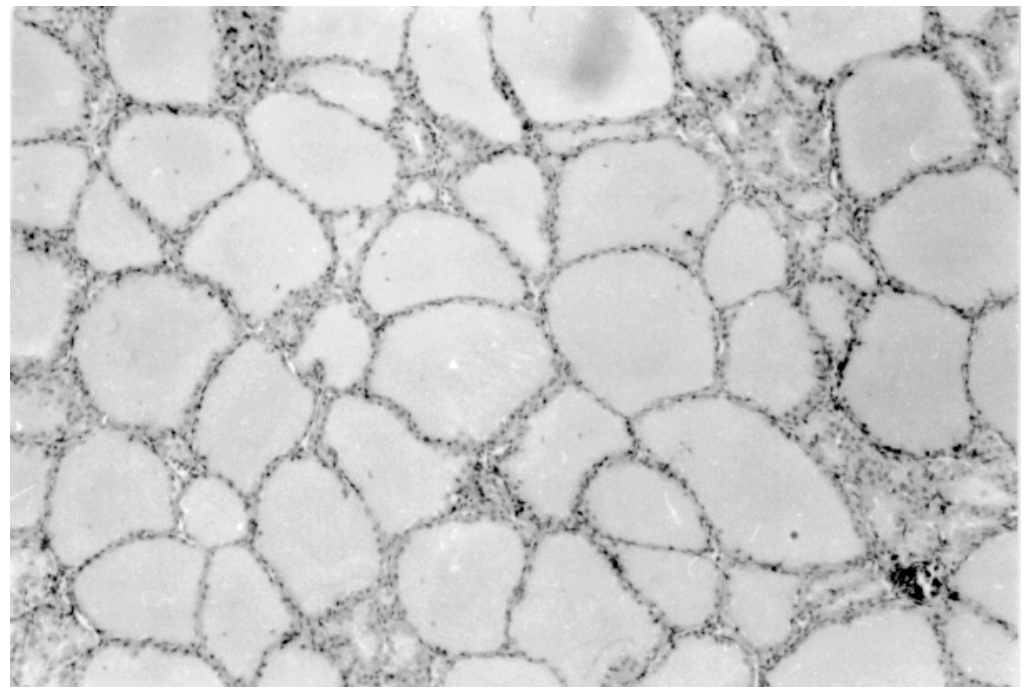

Fig. 4. Section of the thyroid gland from a healthy goose. The uniformly spacious follicles are filled with a vast amount of colloid. Haematoxylin and eosin (H.-E.), $\times 40$

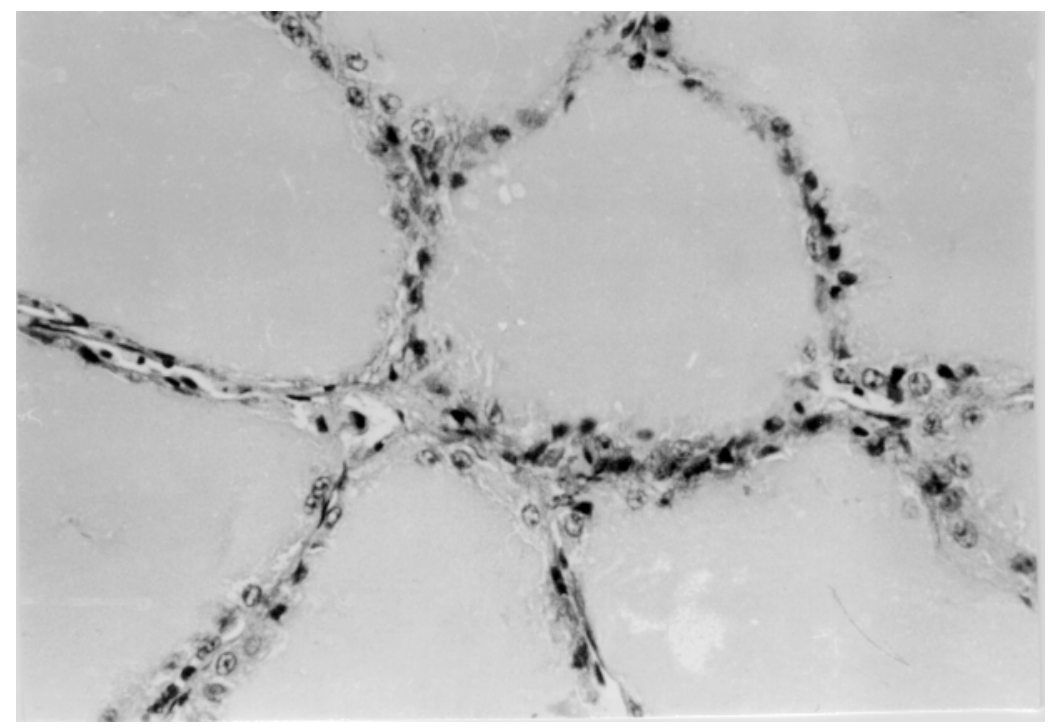

Fig. 5. Section of the thyroid gland from a healthy goose. Follicles are lined by flat or cuboidal epithelium. H.-E., $\times 200$ 


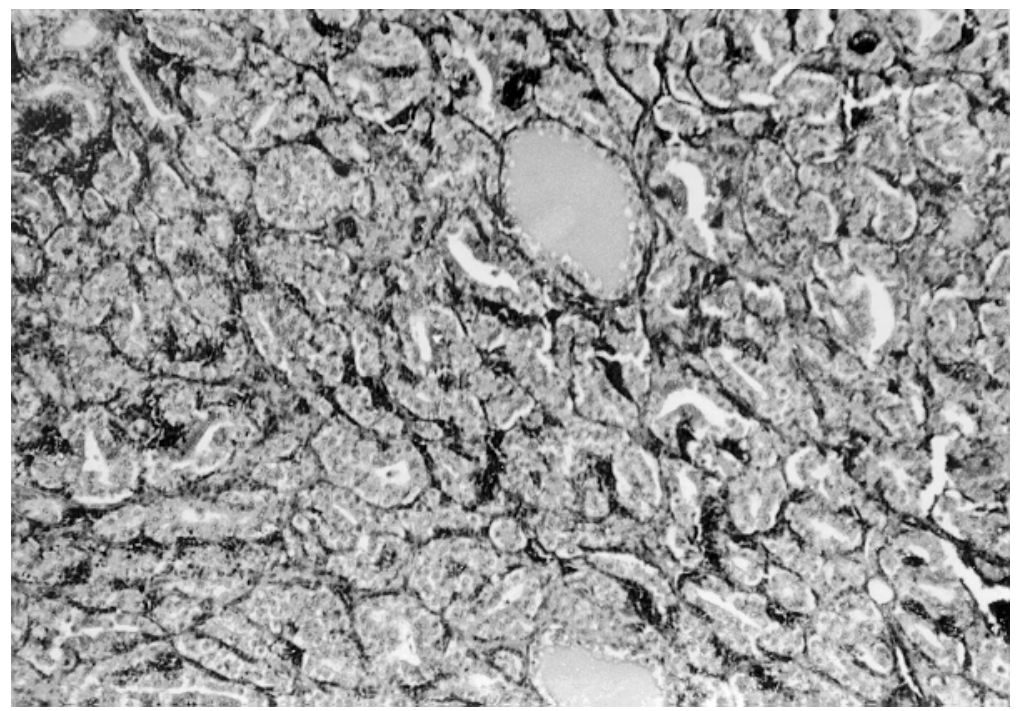

Fig. 6. Parts from a section of the thyroid gland of a diseased goose. The shrunken follicles display no colloid or only traces of colloid. The epithelial layer is thickened. H.-E., $\times 40$

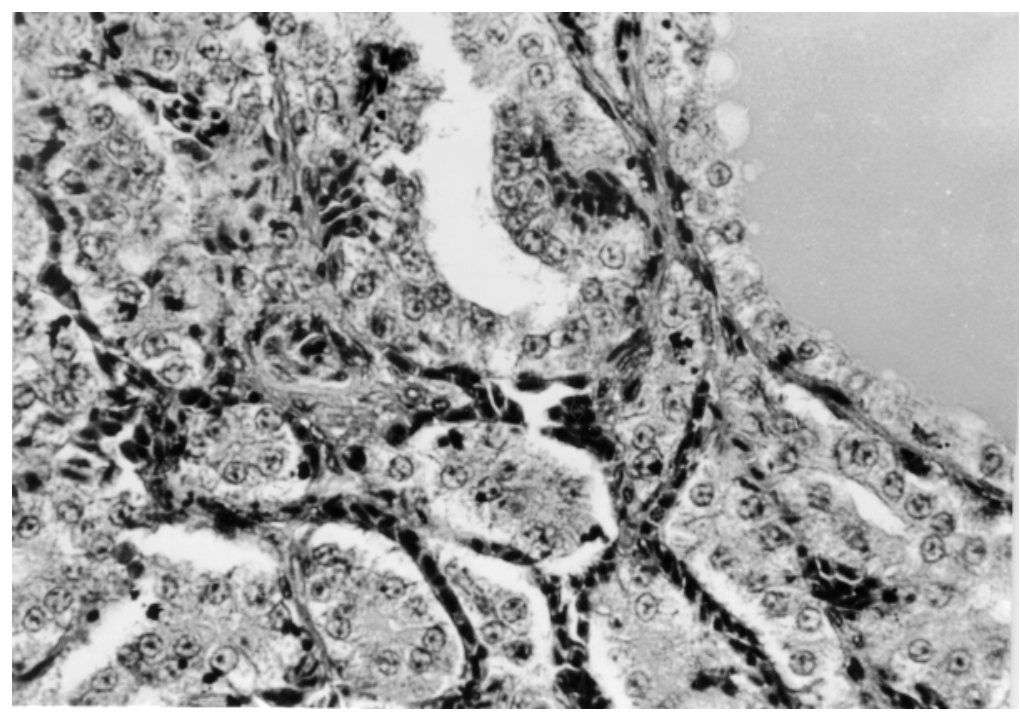

Fig. 7. Parts from a section of the thyroid gland of a diseased goose. The shrunken follicular space does not contain colloid and has multilayered epithelium. The number and diameter of vessels are abnormally large. H.-E., $\times 200$ 


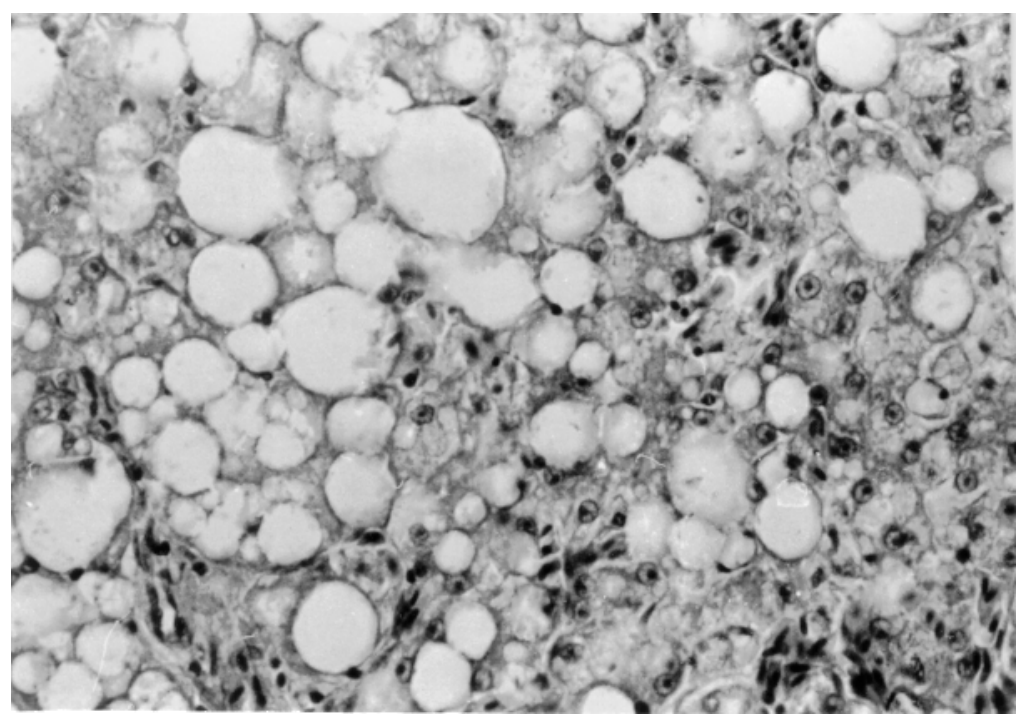

Fig. 8. Parts from a section of the liver of a sick goose. Vacuoles of large diameter with giant lipid droplets are apparent in the hepatocytes. H.-E., $\times 200$

\section{Laboratory animal experiments}

In Group I (birds receiving iodine supplementation) the most apparent clinical signs of the disease, namely the poor development of the plumage, did not disappear during the treatment period. The pathological and histological examinations, however, showed a considerable improvement of the hypothyroid goitre as a response to iodine supplementation. In these birds (bled at the end of the experimental iodine supplementation period) no excess fat accumulation was seen either in the subcutaneous connective tissue or in the mesenteric and abdominal regions. Also the outer appearance and mass of the thyroid glands were very similar to those seen in normal individuals (Table 1). The histology of the thyroid gland also resembled the situation in normal animals. A decreased follicular and colloidal space with multilayered epithelium of cuboidal or cylindrical shape could be found only in about $15-30 \%$ of the thyroidal sections. In this group (Group I) the livers were almost free of fat accumulation and only 25$30 \%$ of the hepatocytes showed signs of slight fat infiltration. No kidney damages were seen.

Group S (geese that received no iodine supplementation in the laboratory) exhibited similar clinical and histological symptoms that were described earlier for the geese affected on the farm. Both the absolute and the relative weight of the thyroid glands decreased in this group (Table 1) but were still significantly $(\mathrm{P}<0.05)$ higher than in the iodine-treated group. 


\section{Thyroxine $\left(T_{4}\right)$ and triiodothyronine $\left(T_{3}\right)$ plasma levels}

The comparison of plasma $T_{4}$ and $T_{3}$ levels in 5 normal control geese (Group N) and 6 clinically affected birds (Group A) at the beginning of the laboratory experiments showed a dramatic difference in hormone levels (Panel A of Table 2). There was no detectable $T_{4}$ and only hypothyroid amounts of $T_{3}$ in the plasma of sick animals (Group A), while the $T_{4}$ and $T_{3}$ values obtained in the five healthy control geese were in the euthyroid physiological range.

The hormone levels changed during the course of the laboratory experiment (Panel B of Table 2) not only in the iodine-supplemented Group I, but also in the non-supplemented Group S. On Day 25 of iodine supplementation $\mathrm{T}_{4}$ and $\mathrm{T}_{3}$ levels were well detectable in Group I and their concentration was about onethird of that in the euthyroid controls. In the non-supplemented group (Group S) $\mathrm{T}_{4}$ and $\mathrm{T}_{3}$ levels were still very low but above the detection limit of the assay. On Day $55 \mathrm{~T}_{4}$ levels in Group I increased to two-thirds of the euthyroid level, while $T_{3}$ values were very close to the euthyroid hormone concentrations. The thyroid hormone levels in the non-supplemented (Group S) animals also increased. This increase was not very much pronounced for $T_{4}$, but for $T_{3}$ the concentrations reached the lowest normal $\mathrm{T}_{3}$ concentrations.

\section{Table 2}

Panel A: The concentration of thyroxine $\left(\mathrm{T}_{4}\right)$ and triiodothyronine $\left(\mathrm{T}_{3}\right)$ in the blood plasma of 5 healthy geese from a non-affected farm (Group N) and of 6 geese displaying goitre (Group A) at the time of discovering the abnormality in the affected farm. Panel B: The same parameters of iodine-treated (Group I) and non-treated sick (Group S) geese at Day 25 and Day 55 of the laboratory experiment $[\mathrm{nmol} / \mathrm{l}$, average \pm SEM $(\mathrm{N})]$. Groups with same superscripts $\left({ }^{\mathrm{a}}\right.$ through $\left.{ }^{\mathrm{d}}\right)$ differ significantly, $\mathrm{P}<0.05$

\begin{tabular}{ccc}
\hline & Healthy geese & Geese displaying goitre \\
\hline \multicolumn{1}{c}{ Panel A } & Group N & Group A \\
\hline $\begin{array}{l}\text { Thyroxine }\left(\mathrm{T}_{4}\right) \\
\text { Triiodothyronine }\left(\mathrm{T}_{3}\right)\end{array}$ & $\begin{array}{r}17.9 \pm 1.11(5)^{\mathrm{a}} \\
1.69 \pm 0.09(5)^{\mathrm{b}}\end{array}$ & $\begin{array}{c}\text { non-detectable }(6)^{\mathrm{a}} \\
0.26 \pm 0.09(6)^{\mathrm{b}}\end{array}$ \\
\hline \multicolumn{1}{c}{ Panel B } & Group I & Group S \\
\hline $\begin{array}{l}\text { Day 25 } \\
\text { Thyroxine }\left(\mathrm{T}_{4}\right)\end{array}$ & $5.98 \pm 1.41(3)^{\mathrm{c}}$ & $0.79 \pm 0.27(3)^{\mathrm{c}}$ \\
Triiodothyronine $\left(\mathrm{T}_{3}\right)$ & $2.02 \pm 0.24(3)$ & $1.15 \pm 0.36(3)$ \\
Day 55 & & $1.32 \pm 0.36(3)^{\mathrm{d}}$ \\
Thyroxine $\left(\mathrm{T}_{4}\right)$ & $11.45 \pm 1.32(3)^{\mathrm{d}}$ & $1.20 \pm 0.21(3)$ \\
Triiodothyronine $\left(\mathrm{T}_{3}\right)$ & $1.99 \pm 0.05(3)$ & \\
\hline
\end{tabular}


The TRH provocation test on Day 0 showed a total lack of thyroidal responsiveness in the diseased animals (Group A) as compared to the five healthy geese (Group N) (Panel A of Table 3). Later on, on Day 25, the TRH provocation test revealed a close to normal pattern in the iodine-supplemented birds (Group I), and also in the non-supplemented animals there was a small but nonnegligible response to TRH provocation (Panel B of Table 3).

\section{Table 3}

Panel A: The results of the TRH provocation test ( $10 \mu \mathrm{g}$ TRH / $\mathrm{kg}$ body weight, i.v.) in 5 healthy geese from a non-affected farm (Group N) and of 6 geese displaying goitre (Group A) at the time of transferring the goitrous geese from the affected farm to the laboratory. Panel B: The same parameters of iodine-treated (Group I) and of untreated sick (Group S) geese at Day 25 of the laboratory experiment. [\% increase of hormone concentrations $40 \mathrm{~min}$ after injecting TRH related to ' 0 ' time hormone concentrations, average \pm SEM $(\mathrm{N})]$. Groups with same superscripts $\left({ }^{a}\right.$ through $\left.{ }^{d}\right)$ differ significantly, $\mathrm{P}<0.05$

\begin{tabular}{ccc}
\hline & Healthy geese & Geese displaying goitre \\
\hline Panel A & Group N & Group A \\
\hline $\begin{array}{c}\text { Thyroxine }\left(\mathrm{T}_{4}\right) \\
\text { Triiodothyronine }\left(\mathrm{T}_{3}\right)\end{array}$ & $\begin{array}{c}201 \pm 7.4(5)^{\mathrm{a}} \\
108 \pm 16(5)^{\mathrm{b}}\end{array}$ & $\begin{array}{c}\text { no detectable change }(6)^{\mathrm{a}} \\
\text { no detectable change }(6)^{\mathrm{b}}\end{array}$ \\
\hline Panel B & Group I & Group S $^{\mathrm{a}}$ \\
\hline Thyroxine $\left(\mathrm{T}_{4}\right)$ & $165 \pm 45(3)^{\mathrm{c}}$ & $47 \pm 10(3)^{\mathrm{c}}$ \\
Triiodothyronine $\left(\mathrm{T}_{3}\right)$ & $17 \pm 5(3)^{\mathrm{d}}$ & $1.9 \pm 0.5(3)^{\mathrm{d}}$ \\
\hline
\end{tabular}

\section{Discussion}

From the previous sections it is clear that the occurrence of goitre (struma parenchymatosa) under normal raising conditions in a geese farm was detected and diagnosed. The underlying clinical symptoms were retarded growth and poor plumage development in a very high percentage of the 2300 geese kept together on the affected farm. Pathological and histological findings as well as the biochemical parameters of the blood plasma provided the final evidence for goitre. Significant enlargement of the thyroids, accumulation of fat in the subcutaneous connective tissue and in the mesenteric region, lipid deposition in liver cells, together with the undetectable thyroxine concentrations, all support this diagnosis.

Even if the diagnosis is supported by the above sound evidence, the cause of goitre development remains unclear. The literature contains numerous reports on goitre in humans and in mammalian animals (Kapp, 1952; Bokori, 1956; 
Baker and Lindsey, 1968; Rac et al., 1968; Antal, 1972; Lissitzky et al., 1973; Kardeván, 1976; de Vijlder et al., 1978; Nesbitt et al., 1980; Gosselin et al., 1980; Milne and Hayes, 1981; Robinson et al., 1988; Capen, 1993) where the major causative factor is the limited access to iodine (Bokori, 1956; Antal, 1972; Capen, 1993). The question arises whether or not the lack of iodine was a causative factor of the goitre in our case. At the first glance the laboratory experiments speak in favour of the supposition that the lack of iodine might have been the major eliciting factor of the goitre. Iodine treatment normalised almost all clinical, pathological and histological symptoms, except plumage growth. However, on closer scrutiny of the laboratory experiments and especially the biochemical parameters thereof (Table 2) it has to be realised that the inability of the thyroid to incorporate iodine into hormones might have been a more important causative factor than the lack of iodine in the diet. This is so because thyroxine and triiodothyronine levels and TRH responses improved not only in the iodine-supplemented group (Group I) but also in the untreated sick geese (Group S) (see Tables 2 and 3). The tendency of biochemical thyroid parameters to normalise in Group $S$ can be realised even better when we compare $T_{4}$ and $T_{3}$ serum levels. $T_{4}$ levels were undetectable in diseased birds at the beginning, but increased to detectable (although low) levels by Day 25 in Group S animals. At the same time, $T_{3}$ levels in these sick geese not receiving iodine supplementation returned to almost normal levels. It is known that in birds the major hormone produced by the thyroid gland is $\mathrm{T}_{4}$ which is later transformed into its active hormone form, triiodothyronine, in the peripheral tissues including the brain, liver, kidney, and other organs (Rudas, 1986). It was also shown that the rate at which the activation of thyroxine into triiodothyronine occurs is determined by the need of the body for $T_{3}$ (Rudas et al., 1993). In the present case an increased, compensatory $T_{4}$ to $T_{3}$ conversion is able to produce close to normal levels of $T_{3}$ in the blood. This can, however, only happen when a minimum amount of $\mathrm{T}_{4}$ is produced by the thyroid. This is clearly the case in Group I and also in Group S. It was seen already at the end of the first 25 days of the laboratory trial, before changing the original diet from the affected farm to maize and before increasing the dose of iodine supplementation. Thus the improvement witnessed in Group S (sick geese not treated with iodine) after transferring them into the laboratory can only be attributed to the release of these animals from an unknown factor present on the affected farm that caused the thyroid to stop its hormone production. Endemic goitre (regional lack of iodine in the feed and in the drinking water) could easily be ruled out, since no goitre occurred in the region of the affected farm. If not the lack of iodine then other factors may have had a possible role in the development of the disease. What are those factors?

Goitre may be elicited by special goitrogens (Kardeván, 1976; Capen, 1993 ) and by excess iodine delivery (Baker and Lindsey, 1968; Antal, 1972) but 
these factors may be excluded in our case, since the diet was the same for group I and Group S in the first 25 days of the laboratory experiments. Plus, if excess iodine had been the cause of goitre then supplementation with iodine should have worsened the condition of the animals, which was apparently not the case. It is also known that glucosinolates in mill cake extracts of rape species may also cause goitre in animals (Wight and Shannon, 1985) but in our case it was known that neither the starter nor the raising feed contained rape. We can rule out the possible goitrogenic effects of the Acremonium species detected in the feed in quite high concentrations. Firstly because these species (Acremonium coenophialum) produce ergotamic toxins not known as goitrogens, and secondly because the same feed was available for both laboratory groups.

One should think rather of a factor that was present on the farm, but not in the laboratory. Among these factors, environmental lead pollution is the one that might cause goitre and decrease the level of thyroid hormones in the blood plasma as shown in ducks (Goldman and Dillon, 1982).

Another possible goitre-eliciting factor that was present on the farm but not in the laboratory might have been the sulphochlorpromazine applied on the farm every six weeks. It is known that this drug may provoke goitre in newborn pig (Blackwell et al., 1989). A proof of overdosing this substance is, however, lacking.

In conclusion: a rare disorder, goitre was diagnosed in a geese flock. The disease may have been elicited by two factors: a relative deficiency of iodine and an undetermined factor that depressed the hormone-producing ability of the geese kept at the farm. An important conclusion from this paper is that the biochemical parameters of thyroid activity, such as plasma levels of thyroxine and triiodothyronine and the results of the TRH provocation test, can signal changes in thyroid status much earlier than pathological and histological investigations.

\section{Acknowledgements}

The authors would like to thank Mrs Zs. Szikora for technical assistance. This work was partly made possible by grant no. 16545 of OTKA (Hungarian Scientific Research Fund) to P. R.

\section{References}

Antal, Á. (1972): Innate struma in lambs (in Hungarian, with English abstract). Magyar Állatorvosok Lapja 27, 544-548.

Baker, H. J. and Lindsey, J. R. (1968): Equine goiter due to excess dietary iodide. J. Am. Vet. Med. Assoc. 153, 616-630. 
Belshaw, B. E. and Rijnberk, A. (1979): Radioimmunoassay of plasma $T_{4}$ and $T_{3}$ in the diagnosis of primary hypothyroidism in dogs. J. Am. Vet. Med. Assoc. 15, 15-23.

Blackwell, T. E., Werdin, R. E., Eisenmenger, M. C. and FitzSimmons, M. A. (1989): Goitrogenic effects in offspring of swine fed sulfadimethoxine and ormetoprim in late gestation. J. Am. Vet. Med. Assoc. 194, 519-523.

Bokori, J. (1956): Innate struma in piglets (in Hungarian, with English abstract). Magyar Állatorvosok Lapja 11, 364-369.

Capen, C. C. (1993): The Endocrine Glands. In: Jubb, K. V. F., Kennedy, P. C. and Palmer, N. (eds) Pathology of Domestic Animals. Fourth edition. Volume 3, Chapter 3, pp. 267-347.

de Vijlder, J. J. M., van Voorthuizen, W. F., van Dijk, J. E., Rijnberk, A. and Tegelaers, W. H. (1978): Hereditary congenital goiter with thyroglobulin deficiency in a breed of goats. Endocrinology 102, 1214-1222.

Janan, J. and Rudas, P. (1998): Interrelationship of thyroid activity with fat metabolism in poultry (in Hungarian, with English abstract). Magyar Állatorvosok Lapja 120, 339-342.

Goldman, M. and Dillon, R. D. (1982): Interaction of selenium and lead on several aspect of thyroid function in Peking ducklings. Res. Comm. Chem. Pathol. Pharmacol. 37, 487-490.

Gosselin, S. J., Capen, C. L., Martin, S. L. and Targowski, S. P. (1980): Biochemical and immunological investigation of hypothyroidism in dogs. Can. J. Comp. Med. 44, 158-168.

Gosselin, S. J., Capen, C. C. and Martin, S. L. (1981): Histopathologic and ultrastructural evaluation of thyroid lesions associated with hypothyroidism in dogs. Vet. Pathol. 18, 299-309.

Kapp, P. (1952): Innate struma in three kids (in Hungarian). Magyar Állatorvosok Lapja 7, 151-153.

Kardeván, A. (1976): Pathology of Domestic Animals (in Hungarian). Mezőgazdasági Kiadó, Budapest.

Lissitzky, S., Bismuth, J., Jaquet, P., Castay, M., Michel-Bechet, M., Koutras, D. A., Pharmakivtis, A. D., Moschas, A., Psarras, A. and Malamos, B. (1973): Congenital goiter with impaired thyroglobulin synthesis. J. Clin. Endocrinol. Metab. 36, 17-29.

Milne, K. L. and Hayes, H. M. (1981): Epidemiologic features of canine hypothyroidism. Cornell. Vet. 71, 3-14.

Nesbitt, G. H., Izzo, J., Peterson, L. and Wilkins, R. J. (1980): Canine hypothyroidism: A retrospective study of 108 cases. J. Am. Vet. Med. Assoc. 177, 1117-1122.

Pammenter, M., van der Walt, B. J. and van Jaarsveld, P. P. (1978): Afrikander cattle congenital goiter: Characteristics of its morphology and iodoprotein pattern. Endocrinology 102, 954-965.

Pethes, G., Losonczy, S. and Rudas, P. (1978a): Measurement of serum triiodothyronine by radioimmunoassay (in Hungarian, with English abstract). Magyar Állatorvosok Lapja 33, $172-176$.

Pethes, G., Losonczy, S. and Rudas, P. (1978b): Short periodical changes in the concentration of hormones of the thyroid gland in the serum of bulls and cows (in Hungarian, with English abstract). Magyar Állatorvosok Lapja 33, 237-242.

Rac, R., Hill, G. N., Pain, R. W. and Wulhearn, C. J. (1968): Congenital goitre in Merino sheep due to an inherited defect in the biosynthesis of thyroid hormone. Res. Vet. Sci. 9, 209-223.

Robinson, W. F., Shaw, S. E., Stanley, B. and Wyburn, R. S. (1988): Congenital hypothyroidism in Scottish deerhound puppies. Aust. Vet. J. 65, 368-389.

Rudas, P. (1986): Comparison of type I 5'-deiodination of thyroxine and of reverse triiodothyronine in rat and chicken liver homogenates. Gen. Comp. Endocrinol. 63, 657-660.

Rudas, P., Bartha, T. and Frenyó, V. L. (1993): Thyroid hormone deiodination in the brain of young chickens acutely adapts to changes in thyroid status. Acta Vet. Hung. 41, 381-393.

Wight, P. A. L. and Shannon, D. W. F. (1985): The morphology of the thyroid glands of quails and fowls maintained on diets containing rapeseed. Avian Pathol. 14, 383-399.

Wisser, J. and Ippen, R. (1991): Zum Vorkommen von Strumen bei Zoovögeln. Wien. Tierärztl. Mschr. 78, 362-365. 